\title{
Multinational Corporations and Local Content Policy: Towards a New Equilibrium
}

\author{
Anne CROWLEY-VIGNEAU \\ Doctoral Candidate \\ University of Reading, Whiteknights, PO Box 217, RG6 6AH, Reading, Berkshire, Unit- \\ ed Kingdom; \\ Lecturer \\ Moscow State Institute of International Relations (MGIMO University), 117454, Ver- \\ nadsky Av., 76, Moscow, Russian Federation \\ E-mail: vigneau.a@my.mgimo.ru \\ ORCID: 0000-0001-7466-2451
}

CITATION: Crowley-Vigneau A. (2020) Multinational Corporations and Local Content Policy: Towards a New Equilibrium. Outlines of Global Transformations: Politics, Economics, Law, vol. 13, no 6, pp. 51-64. DOI: 10.23932/2542-0240-2020-13-6-3

Received: 10.11.2020.

\begin{abstract}
Multinational corporations operate beyond state borders and the need to regulate them has been made apparent by documented human rights violations, as well as environmental encroachments. This article considers two types of measures: (1) those that have been adopted by multinational corporations themselves such as Corporate Social Responsibility initiatives and (2) those developed by host states with a focus on Local Content policy measures. Going beyond the idea of regulating corporations, Local Content policy measures are designed to act as a growth multiplier by developing linkages and involving local populations in the production process to create a spillover effect on the local or national economy. The author reviews the advantages and risks, associated with crafting such policies, and argues that demand for such measures is on the rise, not just in high valueadded industries but also in other spheres. Indeed, while Local Content policies may present some disadvantages, restricting foreign contributions to the production process in an attempt to cultivate local economic
\end{abstract}

linkages, their explicit formulation offers a high degree of clarity to international investors, which could facilitate and regularize the activities of multinational corporations.

KEY WORDS: Multinational Corporations, Local Content Policy, Economic Linkages, International Trade, World Trade Organization, Oil and Gas Industry

\section{Introduction}

Multinational corporations have been the object of much praise, primarily for contributing to a more effective production process as well as to a wider access to goods and services globally. In the mean time they have also elicited much criticism for human rights infringements, environmental damage and insensitivity to the rights of indigenous people. Noam Chomsky's idea that multinational corporations "are granted rights well beyond persons" [O'Callaghan 2016] stands true, when they are regulated neither from within, nor 
from without. States struggle to control the activities of their corporations abroad, and host countries may not have the experience in regulating the activities of largescale businesses nor the means to ensure that national regulations are observed and respected. High-level scandals surrounding the activities of multinational corporations (Enron 2001 for fraud, Nestle 2005 child labor, BP 2010 for oil spill, Volkswagen 2015 for cheating on emissions tests, Uber for infringing on rights of employees 2017, Apple 2017 for consumer rights...) have spurred on the development of corporate social responsibility measures and facilitated the application of stricter control measures.

Both international organizations and national courts played a part in bringing those corporations that violated international laws and ethical norms to justice. Public opinion worldwide, by organizing awareness campaigns and boycotts, has led those multinational corporations to appreciate that it was in their business interest to make sure that all their branches and subsidiaries abide by the principles of their host country as well as of their country of origin. Alongside adhering to ethical, environmental and human rights principles, multinational corporations have seen the list of requirements surrounding their activities expand to include a fair sharing of benefits with the host country and incentives to promote the technological catchup and economic development of the regions where they are active. By requiring multinational corporations to involve a local workforce and businesses in the production process, Local Content Policies (hereinafter also - LC) have helped move from a "taxation and redistribution" to local communities perspective to the more ambitious project of creating a spill-over development effect designed to empower local communities. This article first explores how the activities of multinational corporations affect local and internation- al economic development, revealing the trend of their ever-growing accountability to a multitude of actors. It also offers a theoretical perspective on the benefits and shortcomings of engaging in Local Content policies, arguing that they are becoming an increasingly popular tool to regulate relations between host countries and multinational corporations, both in high value-added industries and in other spheres.

\section{Multinational Corporations: benefits and perils}

Multinational corporations operate in markets the world over and exert a mixed effect on economic development, human rights protection and national regulations. While economic theory provides a convincing analysis of the advantages of specialization and international trade, some experts, especially during the 1990s, challenged the idea that transnational business is beneficial to all parties involved. Meanwhile, researchers maintained that whereas multinational corporations may contribute to a "race to the bottom" in terms of protective legislations in all spheres (human rights, environment, etc.), they could under certain circumstances lead to an improvement of regulation and national practices. More recently it has been demonstrated that multinational corporations, because their behavior is in the limelight and their image depends on their customers' perception of their corporate values and practices, represent forces that could be used to spearhead positive changes.

As noted by some scholars, large-scale transnationalization - meaning the increase in activities taking place beyond national borders - has led to some actors growing in importance and gaining political clout. Hybrid actors have appeared, private organizations sponsored by the state, and some businesses have taken on state functions such as private military companies. Global firms 
increasingly operate in socially embedded markets and are confronted with customers and stakeholders who care about their social and environmental impact. International corporations have undergone major changes, under the impact of globalization, assuming new responsibilities and contributing to spreading good standards of behavior. The impact of transnational corporations has been found to depend on their country of origin and their size, with smaller firms showing themselves more considerate and ready to adapt to the characteristics of the host country than larger efficiency-seeking and standardizing corporations [Kusek, Silver 2018].

At the same time a puzzling paradox can be pointed out: multinational corporations are, on one hand, praised for bringing into host countries international best practices, ethical and environmental norms, but on the other, are expected to adjust to the local context in order to avoid a conflictual relationship with domestic communities. The expectations and understandings of what constitutes a best practice versus what intervenes with and even threatens traditional values are extremely fluid.

While economic theory recognizes both the positive contributions and the negative repercussions of the operations of multinational corporations at a local level, the increase in the number of conflicts between these corporations and local communities has led to a demand for and attempts to develop new institutions and measures holding them accountable for their adverse impact [Jacquinet, Bussotti 2019; Calvano 2008]. On top of the idea of holding multinational corporations responsible for the negative externalities linked to their activities and having them fairly share the profits through taxation, local and national governments have come to expect that international business will also help build up local competence and promote domestic economic development. LC policies appeared in the light of this debate as a tool that local and national governments increasingly resort to in order to encourage and formalize multinational corporations' contribution to the economy of the recipient country.

\section{Defining LC policies}

There is no unique definition of LC Policy in the scholarly literature and the understanding of the concept varies in time and across countries. Some authors focus on the financial results of LC as a policy, defining it as "the composite value contributed to the national economy from the purchase of bought-in goods and services" [Warner 2017, p. 8]. Defining LC as the "share of employment - or of sales to the sector - locally supplied at each stage of this chain" [Tordo, Anouti 2013, p. 2] highlights the market and social implications of such policies. Some authors outline the different levels at which LC policies operate, defining them as "multidimensional and a vehicle for enabling the start up of economic activity, technological catch up, human capital accumulation, and sustaining demand for local goods, work and services. It is also concerned with ownership structure and a transfer of property rights to domestic industrial actors or champions." [Kalyuzhnova \& al. 2016, p. 3].

The idea of "local" is also variable, with some countries requiring within the framework of their LC policies local ownership and locally based activities while others requiring only one of the two [Tordo, Anouti 2013]. The definition of "locals" as nationals has been criticized for neglecting local populations where industrial or extraction activities take place and letting the benefits of LC requirements be "captured by outsiders" [Nwapi 2015, p. 1].

LC policies are not just rules that establish that LC in the production process should be no less that a specific percentage of employment or supply. They are al- 
so long-term policies which declare as their objective to increase over time the part played by local people and resources in the production process [Tordo, Anouti 2013]. LC policy thus appears as a plan to impose and then remove $\mathrm{LC}$ regulations depending on the evolution of a specific industry. Different links have been identified between industrial sectors and LC policies, reflecting the diversity of activities which are directly affected by LC regulations: "backward links" are related to the production process (increasing local employment, ownership and control, encouraging technological sharing with local companies), "forward links" are related to how outputs are processed before they reach the final consumer and "financial links" are concerned with the taxation of activities with a redistributive objective [Tordo, Anouti 2013, pp. 13-15].

Three categories of LC have been identified to highlight its different dimensions and functions: "Market Creating LC", "Sustaining LC" and "Efficiency LC" [Kalyuzhnova \& al. 2016, pp. 12-14]. "Market Creating LC" aims to support the local market when a new type of production activity is launched in a country and the local players are not competitive. In order to avoid foreign players taking over the whole production process, rules are established to make sure LC never falls under a certain threshold, which varies significantly from country to country and from industry to industry. "Sustaining LC" aims to support local producers in conditions of increased international competition, helping them to maintain their market share. The type of support offered to local companies varies and the policies do not typically improve local firms' market share in the short-term [Kalyuzhnova \& al. 2016, p. 12]. "Efficiency LC" has for objective to improve the competitiveness of local firms so that they can in the medium or long term compete in the international arena. "Expansion into international markets" rather than domestic ones is one of the goals [Kalyuzhnova \& al. 2016, p. 13].
LC Policies are commonly used in the oil and gas sector, the automobile sector and other key national industries. In the case of oil and gas, when faced with the discovery of natural resources, governments have the duty to make their exploitation as beneficial as possible for the national economy [Kalyuzhnova \& al. 2016]. If local firms and the local workforce are not competitive enough to contribute significantly to the extraction and production process, then transnational firms can enter and dominate the market, making it virtually impossible for local firms to ever "catch up". Oil discoveries and exploitation in African countries, for example, are affected by skills shortages and a lack of local operational capacity and the need to maximize the benefits for local populations have led to the adoption of LC policies in Angola, Botswana, Gabon, Ghana, Nigeria, South Africa, Tanzania, and Zambia [Nwapi 2016]. The need for LC Policy depends on the level of development of countries and each case is specific: "A less developed economy would need to seek a substitute for market actions" while developed countries stand a better chance of seeing their own firms successfully compete on the market and are consequently less likely to develop LC Policies [Kalyuzhnova \& al. 2016, p. 27].

\section{LC policy tools}

A variety of different instruments have been employed by national governments privileging LC policies, including giving the priority to local employees, home sourcing of goods and services and preferential treatment of local firms [Tordo, Anouti 2013].

The nationalization of the workforce is a common requirement according to which foreign companies operating in countries with LC policies may be obligated to hire in priority local employees, obtain special case-by-case authorization to 
hire foreigners and prove that there were no qualified locals to fill in the position, present their recruitment plans to the government, ensure pay and package equality for foreign and local employees, develop "capacity building programs" to train local employees in order for the foreign workforce to be progressively replaced by local employees and make sure that the local workforce works with new technologies [Tordo, Anouti 2013, p. 27].

A home sourcing of goods clause requires all companies operating in a country in a sector regulated by an LC policy to give priority in their purchasing activities to local services and products used in their production process. Requirements may differ, with some countries ensuring preferential treatment only for non-specialized products and services and others for all products and services [Tordo, Anouti 2013]. Rules may specify the value of contracts below which local firms should be systematically preferred or the percentage higher the price of a local company can be, compared to that of a foreign company, in a tender process in order to win a contract.

Preferential treatment of local firms refers to the help delivered to local companies directly from the state in the framework of a LC policy. Local companies can be offered tax relief, financial aide for their development, bailing out in extreme cases, access to financial funds for training local staff, advantageous loans and other advantages [Tordo, Anouti 2013].

\section{Local and International Effects of LC policies}

There are a number of reasons why governments intervene in free-market mechanisms and create LC policies. The World Bank recognizes that some of the benefits of LC policies are to "increase value-added", to "correct market failure" and to "support employment and other social objectives" [Tordo, Anouti 2013, p. 34]. Local firms may not have developed the expertise to participate in the exploitation of newly found natural resources, and governments implement new rules in order to reap the economic benefits related to these new activities. The goals of LC policies may be to overcome or avoid the "resource curse" [Ross 2013, p. 1] by promoting a country's economic diversification, or to support corporations in the "discovery" of new resources, as this first phase of activities may not always be compensated by market mechanisms. LC policies also aim to support local workers by promoting by different means their employment, the development of their skills and their mastery of new technologies. Knowledge sharing can also benefit other economic sectors in the country. Supporting local companies and small and medium enterprises can be a way of correcting market mechanisms as large multinational corporations can lead smaller ones to bankruptcy and eject them from the market by using economies of scale or dumping practices. LC policies supporting local employment can be created with the aim to reduce unemployment rates or by governments that want for nationals to participate in the exploitation of national resources. Last of all, LC policies can be used to compensate locals for negative externalities such as environmental degradation linked to the activities of the $\mathrm{O} \& \mathrm{G}$ industry.

LC measures are widely adopted by states and some authors claim "that virtually all of the small number of non-western economies that achieved "developed" economic status in the past two centuries have used industrial policy to impart directional thrust aimed at catching up with western economies" [Wade 2015, p. 67]. The need for the state to play a role in industrialization was pointed out early on by Amsden (1989), who went on to describe in detail the differences between early and late industrialization, noting that in the latter case, 
productivity does not depend on breakthroughs but on countries' ability to learn how to manufacture products which have already reached maturity in the international arena [Amsden, Chu 2003]. The lack of large-scale firms puts developing countries at a disadvantage on the global market. Governments can effectively support their industrial development by adapting prices and encouraging investments [Lin 2016].

This does not mean however that these policies are widely accepted as beneficial and do not present any economic risks.

There is abundant literature criticizing LC policies, emphasizing their inefficiency, the vested interests they promote and how they contradict the fundamental rules of international trade. Some economists point out the government failures by omission and commission in development policies, noting that government failure notably outweighs market failure While governments tried to correct market imbalances, the results of their interventions in the long term were more detrimental than market failure itself. Named "double-market failure", the conventional market failure (involving negative externalities and information asymmetry) combined with the failure of state intervention (aimed at fixing the market failure) appears to some as a likely outcome of LC policies [Warner 2017]. It has also been noted that a government's choice of trade-policy is always influenced by special-interest groups and it often opts for trade policies to transfer income rather than resort to more economically efficient means [Grossman, Helpman 1991]. The risks of corruption are high when intervening in market mechanisms to favor some companies over others and political LC policies have been shown to be largely unsustainable [Lima-de-Oliveira 2020]. Helping a specific sector may lead to market distortions [Bhagwati 1988] and other industries may suffer from the preferential treatment policy. Additionally, competition leads to an optimal allocation of resources and LC requirements for firms to source locally may drive up production prices leading to inefficiency in the production process [Grossman 1981]. LC policies are also often concealed behind new ecological and health and safety requirements.

Alongside these issues, a lot of LC policies are prohibited by the WTO as they violate the GATT requirements, the Agreement on Subsidies and Countervailing Measures (ASCM) and the Agreement on Trade-Related Investment Measures [Rabiu 2013; Nwapi 2016]. The "national treatment" put forward in all these documents requires countries to treat firms from other countries in the same way as they would their own. Local subsidies are only allowed if they do not affect the domestic commerce of other countries according to WTO rules [Nwapi 2016]. While most LC policies breach WTO rules, some allowances have been made for developing countries, which get a timelimited authorization to use protectionist measures [Tordo, Anouti 2013]. The O\&G industry, because it has not been negotiated as a separate category under the GATT agreement, still offers states some scope for intervention [Tordo, Anouti 2013]. The benefits of LC policies have been shown to be superior at a regional level than at a national level, with experts underlining that a larger spatial dimension allows more opportunities for linkage developments [Atienza \& al. 2020].

An extensive review of LC policies by World Bank experts generated a number of recommendations as to how to reduce the economic and systemic risks of implementing LC regulations. They pointed out the need to make sure that LC Policies are consistent with other economic policies of the country, that they support local firms in becoming more efficient rather than simply protecting them from foreign competition, that they correct market inefficiency by reducing information asymmetry, that they encourage technological 
development and the improvement of local skills, that they are not heavy technical and administrative burdens for businesses and that they encourage the development of synergies between various industries [Tordo, Anouti 2013]. The need to adapt LC policies over time, to estimate the risks and benefits before launching any LC policy, to establish clear goals, to decide in advance who is accountable for and responsible for monitoring the new policy and to clearly communicate on the objec- tives of LC policies has also been pointed out [Klueh \& al. 2007].

LC policies are not "one size fits all", and voluntary initiatives undertaken by firms may yield better results than mandatory quantitative targets in some contexts [Korinek, Ramdoo 2017].

The concept of LC policy could be used beyond the spheres it is traditionally applied to. Research on specific aspects of LC policies has led to discussions regarding the utility of developing local requirements for

Table 1. Advantages and Drawbacks of Different LC Policy Measures

\begin{tabular}{|c|c|c|c|}
\hline LC Policies & Pros & Cons & Literature \\
\hline $\begin{array}{l}\text { Quotas on local } \\
\text { employment }\end{array}$ & $\begin{array}{l}\text { Supporting employment of } \\
\text { local people helps support } \\
\text { communities }\end{array}$ & $\begin{array}{l}\text { Restrictions on migrant labor } \\
\text { reduce productivity }\end{array}$ & $\begin{array}{l}\text { [Warner 2017; Adedeji \& al. } \\
\text { 2016; Tordo, Anouti 2013]. }\end{array}$ \\
\hline $\begin{array}{l}\text { Quotas on local sourcing } \\
\text { of goods and services }\end{array}$ & $\begin{array}{l}\text { Offering development oppor- } \\
\text { tunities to local companies } \\
\text { which may suffer from for- } \\
\text { eign companies' pre-exist- } \\
\text { ing relationship with foreign } \\
\text { suppliers }\end{array}$ & $\begin{array}{l}\text { Local produce/services may } \\
\text { not be cost-efficient, discour- } \\
\text { aging foreign imports can } \\
\text { distort market mechanisms }\end{array}$ & $\begin{array}{l}\text { [Dixon \& al. 2018; Warner } \\
\text { 2017; Eikeland, Nilsen 2016; } \\
\text { Hufbauer \& al. 2013]. }\end{array}$ \\
\hline $\begin{array}{l}\text { Knowledge-sharing/ } \\
\text { Technology transfer } \\
\text { requirements }\end{array}$ & $\begin{array}{l}\text { Developing local capacity: Lo- } \\
\text { cal firms acquire the know- } \\
\text { how to be able to operate } \\
\text { more independently over } \\
\text { time/ local employees devel- } \\
\text { op their skill set }\end{array}$ & $\begin{array}{l}\text { International firms can- } \\
\text { not protect their trade se- } \\
\text { crets, loss of value, risk they } \\
\text { will not have a return on in- } \\
\text { vestment }\end{array}$ & $\begin{array}{l}\text { [Davies 2016; Asghari, Rakh- } \\
\text { shanikia 2013; Mabadi 2007]. }\end{array}$ \\
\hline $\begin{array}{l}\text { Limiting foreign } \\
\text { ownership/ control } \\
\text { on operations }\end{array}$ & $\begin{array}{l}\text { The government and its citi- } \\
\text { zens retain control on natural } \\
\text { resources/industry }\end{array}$ & $\begin{array}{l}\text { Risky investment climate may } \\
\text { drive foreign firms away }\end{array}$ & $\begin{array}{l}\text { [Jasimuddin, Maniruzza- } \\
\text { man 2016; Wilson 2015; } \\
\text { Kretzschmar \& al. 2010]. }\end{array}$ \\
\hline $\begin{array}{l}\text { Financial incentives } \\
\text { for local firms }\end{array}$ & $\begin{array}{l}\text { Helping "fledgling firms" or } \\
\text { key industries }\end{array}$ & $\begin{array}{l}\text { Higher consumer prices, neg- } \\
\text { ative impact on trade, depen- } \\
\text { dence on subsidies, risk of } \\
\text { corruption }\end{array}$ & $\begin{array}{l}\text { [Kalyuzhnova, Belitski 2019; } \\
\text { Erokhin 2017; Wade 2015; } \\
\text { Busch, Pelc 2014]. }\end{array}$ \\
\hline $\begin{array}{l}\text { Taxation of activities } \\
\text { of foreign firms }\end{array}$ & $\begin{array}{l}\text { Ensuring the local popula- } \\
\text { tion benefits from the natu- } \\
\text { ral resources and activities on } \\
\text { their territory/ spill-over of } \\
\text { the wealth on other econom- } \\
\text { ic sectors }\end{array}$ & $\begin{array}{l}\text { Discouraging foreign invest- } \\
\text { ments by reducing profits }\end{array}$ & $\begin{array}{l}\text { [Obeng-Odoom 2019; Ayenti- } \\
\text { mi \& al. 2016]. }\end{array}$ \\
\hline $\begin{array}{l}\text { Financial incentives } \\
\text { to local firms }\end{array}$ & $\begin{array}{l}\text { Supporting infant industries. } \\
\text { Promoting economic diversi- } \\
\text { fication in the region, avoid- } \\
\text { ing a "resource curse" }\end{array}$ & $\begin{array}{l}\text { Making local firms dependent } \\
\text { on subsidies. Infringing WTO } \\
\text { rules on protectionism. }\end{array}$ & $\begin{array}{l}\text { [Nwapi 2016; Kolstad, Kinyon- } \\
\text { do 2016; Hestermeyer, Nielsen } \\
\text { 2014; Ross 2013]. }\end{array}$ \\
\hline
\end{tabular}

Source: Author's compilation. 
foreign aid procurement [Warner 2017], for renewable forms of energy [Kuntze, Moerenhout 2013], in the healthcare industry [Hufbauer \& al. 2013]. Many authors focus on the economic and financial aspects of LC policies, however Tordo \& Anouti (2013) argue that LC may be guided more by political imperatives than financial reasons. Indeed it would seem most countries did not consider the "costs and benefits of alternative policy options" before implementing LC policies [Tordo, Anouti 2013, p. xiii]. This consideration opens the door to a wider understanding of LC policies, which may be designed for political, security or other reasons. An example is Brazil's "new developmentalism" and its LC regulations which are designed to optimally exploit its large oil reserves but also to preserve its "clean energy matrix" which relies $50 \%$ on renewable sources of energy [Schutte 2013, pp. 17-19]. In this case, market mechanisms are deliberately restricted in the light of environmental concerns.

One can draw a parallel between LC requirements in the energy and resources industry, and policies designed to enhance the local contribution to projects realized in the educational, environmental or any other spheres. While the huge financial impact of projects in the oil and gas industry (and other high value-added industries) can explain a country's decision to implement LC Policies; it may be that LC regulations, under another name, are also being implemented in other spheres. While the financial incentive to promote LC policies in the realization of educational, cultural or other projects may be less decisive, governments may have political or other reasons to encourage firms, universities and other players to choose local rather than international players when carrying out projects. Beyond political and financial reasons, governments may decide to promote LC simply because they are convinced that branding a project or a product as local makes it more popular, easi- er to sell locally and most successful in its implementation. In the LC logic, patriotic sentiments ("the benefits of buying locally grown produce") are sometimes coupled with environmental ones ("best buy food which has not flown over from across the globe"). The 2019 outbreak of the Coronavirus pandemic, with the travel and transport limitations it brought about, may reinforce the localization trend as the risks of reliance on foreign corporations are exposed and the local need for jobs increases due to economic hardship.

\section{Conclusion}

The lasting debate between proponents of unrestricted free trade and critics of unregulated multinational corporations has found a new ground for development with the implementation of Local Content policies. While associated by some with unnecessary protectionism, LC policies are growing in popularity in a highly globalized world as the dissatisfaction of domestic communities with what is perceived to be a foreign intervention continues to grow. LC policies may restrict foreign contributions to the production process in an attempt to develop local economic linkages, but their explicit formulation offers a high degree of clarity to international investors. In other words, formalizing local requirements by developing Local Content policies may be better for all stakeholders than letting a conflict-prone situation escalate to the point when the government intervenes unexpectedly with nationalization or other more radical measures.

\section{References}

Adedeji A.N., Sidique S.F., Rahman A.A., Law S.H. (2016) The Role of Local Content Policy in Local Value Creation in Nigeria's Oil Industry: A Struc- 
tural Equation Modeling (SEM) Approach. Resources Policy, no 49, pp. 61-73. DOI: 10.1016/j.resourpol.2016.04.006

Amsden A.H. (1989) Asia's Next Giant: South Korea and Late Industrialization, Oxford, UK: Oxford University Press.

Amsden A.H., Chu W.W. (2003) Beyond Late Development: Taiwan's Upgrading Policies, Cambridge, MA: The MIT Press.

Asghari M., Rakhshanikia M.A. (2013) Technology Transfer in Oil Industry, Significance and Challenges. Procedia - Social and Behavioral Sciences, no 75, pp. 264271. DOI: 10.1016/j.sbspro.2013.04.030

Atienza M., Arias-Loyola M., Lufin M. (2020) Building a Case for Regional Local Content Policy: The Hollowing out of Mining Regions in Chile. The Extractive Industries and Society, vol. 7, no 2, pp. 292-301. DOI: 10.1016/j.exis.2019.11.006

Ayentimi D.T., Burgess J., Brown K. (2016) Developing Effective Local Content Regulations in sub-Sahara Africa: The Need for More Effective Policy Alignment. Multinational Business Review, vol. 24, no 4, pp. 354374. DOI: 10.1108/MBR-08-2015-0040

Bhagwati J.N. (1988) Protectionism, Cambridge: MIT Press.

Busch M.L., Pelc K.J. (2014) Law, Politics, and the True Cost of Protectionism: The Choice of Trade Remedies or Binding Overhang. World Trade Review, vol. 13, no 1, pp. 39-64.DOI: 10.1017/S1474745613000220

Calvano L. (2008) Multinational Corporations and Local Communities: A Critical Analysis of Conflict. Journal of Business Ethics, vol. 82, no 4, pp. 793-805. DOI: $10.1007 / \mathrm{s} 10551-007-9593-\mathrm{Z}$

Davies M. (2016) Technology Transfer and North-South. Review of International Economics, vol. 24, no 3, pp. 447-483. DOI: $10.1111 /$ roie. 12206

Dixon P.B., Rimmer M.T., Waschik R.G. (2018) Evaluating the Effects of Local Content Measures in a CGE Model: Eliminating the US buy America(n) Programs. Economic Modelling, vol. 68, pp. 155-166. DOI: 10.1016/j.econmod.2017.07.004
Eikeland S., Nilsen T. (2016) Local Content in Emerging Growth Poles: Local Effects of Multinational Corporations' Use of Contract Strategies. Norsk Geografisk Tidsskrift - Norwegian Journal of Geography, vol. 70, no 1, pp. 13-23. DOI: 10.1080/00291951.2015.1108361

Erokhin V. (2017) Self-sufficiency versus Security: How Trade Protectionism Challenges the Sustainability of the Food Supply in Russia. Sustainability, vol. 9, no 11, 1939. DOI: 10.3390/su9111939

Grossman G.M. (1981) The Theory of Domestic Content Protection and Content Preference. The Quarterly Journal of Economics, vol. 96, no 4, pp. 583-603. DOI: $10.2307 / 1880742$

Grossman J., Helpman E. (1991) Quality Ladders in the Theory of Growth. The Review of Economic Studies, vol. 58, no 1, pp. 43-61. DOI: $10.2307 / 2298044$

Hestermeyer H.P., Nielsen L. (2014) The Legality of Local Content Measures under WTO Law. Journal of World Trade, vol. 48, no 3, pp. 553-591. Available at: https://www.researchgate.net/publication/279321597_The_Legality_of_Local_ Content_Measures_under_WTO_Law, accessed 30.11.2020.

Hufbauer G., Schott J.J., Wada E., Cimino C., Vieiroand M. (2013) Local Content Requirements: A Global Problem, Washington: Peterson Institute for International Economics.

Jacquinet M., Bussotti L. (2019) Managing Sustainability: The Role of Multinational Corporations in the Global South. Problems of Management in the 21st Century, vol. 14, no 1, pp. 42-53. DOI: $10.33225 / \mathrm{pmc} / 19.14 .42$

Jasimuddin S.M., Maniruzzaman M. (2016) Resource Nationalism Specter Hovers over the Oil Industry: The Transnational Corporate Strategy to Tackle Resource Nationalism Risks. Journal of Applied Business Research (JABR), vol. 32, no 2, pp. 387-400. DOI: 10.19030/jabr.v32i2.9584

Kalyuzhnova Y., Belitski M. (2019) The Impact of Corruption and Local Content 
Policy on Firm Performance: Evidence from Kazakhstan. Resources Policy, vol. 61, pp. 6776. DOI: 10.1016/j.resourpol.2019.01.016

Kalyuzhnova Y., Nygaard C.A., Omarov Y., Saparbayev A. (2016) Local Content Policies in Resource-rich Countries, London, UK: Palgrave Macmillan.

Klueh U.H., Pastor G., Segura A., Zarate W. (2007) Inter-sectoral Linkages and Local Content in Extractive Industries and Beyond--the Case of São Tomé and Príncipe. IMF Working Papers. WP/07/213. Available at: https://www.imf.org/external/ pubs/ft/wp/2007/wp07213.pdf, accessed 30.11.2020.

Kolstad I., Kinyondo A. (2016) Alternatives to Local Content Requirements in Resource-rich Countries. Oxford Development Studies, vol. 45, no 4, pp. 409-423. DOI: 10.1080/13600818.2016.1262836

Korinek J., Ramdoo I. (2017) Local Content Policies in Mineral-exporting Countries. OECD Trade Policy $\mathrm{Pa}$ pers, No 209. Paris: OECD Publishing. DOI: $10.1787 / 4 b 9 b 2617$-en

Kretzschmar G.L., Kirchner A., Sharifzyanova L. (2010) Resource Nationalism - Limits to Foreign Direct Investment. The Energy Journal, vol. 31, no 2, pp. 27-52. DOI: 10.5547/ISSN0195-6574-EJ-Vol31-No2-2

Kuntze J.C., Moerenhout T. (2013) Local Content Requirements and the Renewable Energy Industry - A Good Match? Geneva, Switzerland: International Centre for Trade and Sustainable Development.

Kusek P., Silva A. (2018) What Investors Want: Perceptions and Experiences of Multinational Corporations in Developing Countries, The World Bank.

Lima-de-Oliveira R. (2020) Corruption and Local Content Development: Assessing the Impact of the Petrobras' Scandal on Recent Policy Changes in Brazil. The Extractive Industries and Society, vol. 7, no 2, pp. 274282. DOI: 10.1016/j.exis.2019.08.004

Lin J. (2016) Alice H. Amsden's Contributions to Development Economics. Cambridge Journal of Regions, Econ- omy and Society, vol. 10, no 1, pp. 77-81. DOI: $10.1093 /$ cjres/rsw040

Mabadi A.H. (2007) Transfer of Technology in Oil and Gas Contracts. SSRNElectronic Journal. DOI: 10.2139/ssrn.1745426

Nwapi C. (2015) Defining the "Local" in Local Content Requirements in the Oil and Gas and Mining Sectors in Developing Countries. Law and Development Review, vol. 8, no 1, pp. 187-216. DOI: $10.1515 / \mathrm{ldr}-2015-0008$

Nwapi C. (2016) A Survey of the Literature on Local Content Policies in the Oil and Gas Industry in East Africa. The School of Public Policy, SPP Technical Paper, University of Calgary OECD.

O'Callaghan T. (2016) Reputation Risk and Globalisation: Exploring the Idea of a Self-Regulating Corporation, Edward Elgar Publishing.

Obeng-Odoom F. (2019) Oil, Local Content Laws and Paternalism: Is Economic Paternalism Better Old, New or Democratic? Forum for Social Economics, vol. 48, no 3, pp. 281-306. DOI: $10.1080 / 07360932.2016 .1197844$

Rabiu A. (2013) Local Content Policy and the WTO Rules of Trade Related Investment Measures (TRIMS): The Pros and Cons. International Journal of Business and Management Studies, vol. 2, no 1, pp. 137-146. Available at: http://universitypublications.net/ijbms/0201/ pdf/RHS405.pdf, accessed 30.11.2020.

Ross M. (2013) The Oil Curse: How Petroleum Wealth Shapes the Development of Nations, Princeton University Press.

Schutte G. (2013) Brazil: New Developmentalism and the Management of Offshore Oil Wealth. Revista Europea De Estudios Latinoamericanos $Y$ Del Caribe (European Review of Latin American and Caribbean Studies), no 95, pp. 4970. Available at: https://www.jstor.org/ stable/23595692? seq=1\#metadata_info_ tab_contents, accessed 30.11.2020.

Tordo S., Anouti Y. (2013) Local Content in the Oil and Gas Sector: Case Studies, World Bank Publication. 
Wade R. (2015) The Role of Industrial Policy in Developing Countries. Rethinking Development Strategies after the Financial Crisis - Volume I: Making the Case for Policy Space (eds. Calcagno A. et al.), pp. 67-78. UNCTAD.

Warner M. (2017) Local Content in Procurement: Creating Local Jobs and Compet- itive Domestic Industries in Supply Chains, London: Routledge.

Wilson J.D. (2015) Understanding Resource Nationalism: Economic Dynamics and Political Institutions. Contemporary Politics, vol. 21, no 4, pp. 399-416. DOI: 10.1080/13569775.2015.1013293

\title{
Транснациональные корпорации и стратегия локализации: к новому равновесию?
}

\author{
Анн ВИНьо \\ аспирант \\ University of Reading, Whiteknights, PO Box 217, RG6 6AH, Reading, Berkshire, \\ United Kingdom; \\ преподаватель \\ Московский государственный институт международных отношений МИД \\ России, 117454, проспект Вернадского, д. 76, Москва, Российская Федерация \\ E-mail: vigneau.a@my.mgimo.ru \\ ORCID: 0000-0001-7466-2451
}

ЦИТИРОВАНИЕ: Crowley-Vigneau А. (2020) Multinational Corporations and Local Content Policy: Towards a New Equilibrium. Outlines of Global Transformations: Politics, Economics, Law, vol. 13, no 6, pp. 51-64. DOI: 10.23932/2542-0240-2020-13-6-3

Статья поступила в редакцию 10.11.2020.

\begin{abstract}
АННОТАЦИЯ. По мере увеличения масштаба деятельности транснациональных корпораций и накопления данных о сопутствуюших ей нарушениях прав человека и ущербе окружающей среде необходимость регламентации функиионирования ТНК становится все более очевидной. В данной статье рассматриваются два типа мер: 1) те, которые были приняты самими транснациональными корпорациями, например инициативы в области корпоративной соииальной ответственности, и 2) те, которье были разра-
\end{abstract}

ботаны принимающими государствами с акцентом на стратегии локализаиии. Элементы стратегии локализаиии (или, как ее называют в зарубежной литературе, политики «местного содержания»), не ограничиваясь идеей только регулирования деятельности корпораций, призваны служить в качестве мультипликатора национального роста путем развития связей и вовлечения местного населения в экономический проиесс для создания дополнительных положительных эфбектов c точки зрения усиления потенциа- 
ла развития регионального или национального хозяйства. В статье анализируются преимущества и риски, связанные с разработкой такой политики. Автор утверждает, показывая это на основе обширного обзора титератуpы, что запрос на такие меры возрастает не только в отраслях с высокой добавленной стоимостью, но и в иелом в экономике. Более того, в то время как стратегия локализации может иметь ряд недостатков, например, сдерживая положительные последствия иностранных инвестииий с точки зрения трансфера идущих вместе с ними технологий, компетениий и управленческого опыта, ее четкое декларирование органами государственной власти обеспечивает более высокую степень прозрачности инвестииионной средь, что в долгосрочном периоде повышает заинтересованность международного бизнеса.

КЛЮЧЕВЫЕ СЛОВА: транснациональные корпорации, политика локализаиии, экономические связи, международная торговля, Всемирная торговая организация, нефтегазовая промыштенность

\section{Список литературы}

Adedeji A.N., Sidique S.F., Rahman A.A., Law S.H. (2016) The Role of Local Content Policy in Local Value Creation in Nigeria's Oil Industry: A Structural Equation Modeling (SEM) Approach // Resources Policy, no 49, pp. 61-73. DOI: 10.1016/j.resourpol.2016.04.006

Amsden A.H. (1989) Asia's Next Giant: South Korea and Late Industrialization, Oxford, UK: Oxford University Press.

Amsden A.H., Chu W.W. (2003) Beyond Late Development: Taiwan's Upgrading Policies, Cambridge, MA: The MIT Press.
Asghari M., Rakhshanikia M.A. (2013) Technology Transfer in Oil Industry, Significance and Challenges // Procedia - Social and Behavioral Sciences, no 75, pp. 264271. DOI: $10.1016 /$ j.sbspro.2013.04.030

Atienza M., Arias-Loyola M., Lufin M. (2020) Building a Case for Regional Local Content Policy: The Hollowing out of Mining Regions in Chile // The Extractive Industries and Society, vol. 7, no 2, pp. 292301. DOI: 10.1016/j.exis.2019.11.006

Ayentimi D.T., Burgess J., Brown K. (2016) Developing Effective Local Content Regulations in sub-Sahara Africa: The Need for More Effective Policy Alignment // Multinational Business Review, vol. 24, no 4, pp. 354-374. DOI: 10.1108/MBR-08-2015-0040

Bhagwati J.N. (1988) Protectionism, Cambridge: MIT Press.

Busch M.L., Pelc K.J. (2014) Law, Politics, and the True Cost of Protectionism: The Choice of Trade Remedies or Binding Overhang // World Trade Review, vol. 13, no 1, pp. 39-64. DOI: $10.1017 /$ S1474745613000220

Calvano L. (2008) Multinational Corporations and Local Communities: A Critical Analysis of Conflict // Journal of Business Ethics, vol. 82, no 4, pp. 793-805. DOI: $10.1007 / \mathrm{s} 10551-007-9593-\mathrm{Z}$

Davies M. (2016) Technology Transfer and North-South // Review of International Economics, vol. 24, no 3, pp. 447483. DOI: $10.1111 /$ roie. 12206

Dixon P.B., Rimmer M.T., Waschik R.G. (2018) Evaluating the Effects of Local Content Measures in a CGE Model: Eliminating the US buy America(n) Programs // Economic Modelling, vol. 68, pp. 155-166. DOI: 10.1016/j.econmod.2017.07.004

Eikeland S., Nilsen T. (2016) Local Content in Emerging Growth Poles: Local Effects of Multinational Corporations' Use of Contract Strategies // Norsk Geografisk Tidsskrift - Norwegian Journal of Geography, vol. 70, no 1, pp. 13-23. DOI: $10.1080 / 00291951.2015 .1108361$ 
Erokhin V. (2017) Self-sufficiency versus Security: How Trade Protectionism Challenges the Sustainability of the Food Supply in Russia // Sustainability, vol. 9, no 11, 1939. DOI: 10.3390/su9111939

Grossman G.M. (1981) The Theory of Domestic Content Protection and Content Preference // The Quarterly Journal of Economics, vol. 96, no 4, pp. 583-603. DOI: $10.2307 / 1880742$

Grossman J., Helpman E. (1991) Quality Ladders in the Theory of Growth // The Review of Economic Studies, vol. 58, no 1, pp. 43-61. DOI: 10.2307/2298044

Hestermeyer H.P., Nielsen L. (2014) The Legality of Local Content Measures under WTO Law // Journal of World Trade, vol. 48, no 3, pp. 553-591// https://www.researchgate.net/publication/ 279321597_The_Legality_of_Local_Content_Measures_under_WTO_Law, дата обращения 30.11.2020.

Hufbauer G., Schott J.J., Wada E., Cimino C., Vieiroand M. (2013) Local Content Requirements: A Global Problem, Washington: Peterson Institute for International Economics.

Jacquinet M., Bussotti L. (2019) Managing Sustainability: The Role of Multinational Corporations in the Global South // Problems of Management in the 21st Century, vol. 14, no 1, pp. 42-53. DOI: $10.33225 / \mathrm{pmc} / 19.14 .42$

Jasimuddin S.M., Maniruzzaman M. (2016) Resource Nationalism Specter Hovers over the Oil Industry: The Transnational Corporate Strategy to Tackle Resource Nationalism Risks // Journal of Applied Business Research (JABR), vol. 32, no 2, pp. 387400. DOI: 10.19030/jabr.v32i2.9584

Kalyuzhnova Y., Belitski M. (2019) The Impact of Corruption and Local Content Policy on Firm Performance: Evidence from Kazakhstan // Resources Policy, vol. 61, pp. 67-76. DOI: 10.1016/j.resourpol.2019.01.016

Kalyuzhnova Y., Nygaard C.A., Omarov Y., Saparbayev A. (2016) Local Con- tent Policies in Resource-rich Countries, London, UK: Palgrave Macmillan.

Klueh U.H., Pastor G., Segura A., Zarate $W$. (2007) Inter-sectoral Linkages and Local Content in Extractive Industries and Beyond--the Case of São Tomé and Príncipe // IMF Working Papers. WP/07/213 $/ /$ https://www.imf.org/external/pubs/ft/ wp/2007/wp07213.pdf, дата обращения 30.11.2020.

Kolstad I., Kinyondo A. (2016) Alternatives to Local Content Requirements in Resource-rich Countries // Oxford Development Studies, vol. 45, no 4, pp. 409-423. DOI: 10.1080/13600818.2016.1262836

Korinek J., Ramdoo I. (2017) Local Content Policies in Mineral-exporting Countries // OECD Trade Policy Papers, No 209. Paris: OECD Publishing. DOI: $10.1787 / 4 b 9 b 2617$-en

Kretzschmar G.L., Kirchner A., Sharifzyanova L. (2010) Resource Nationalism - Limits to Foreign Direct Investment // The Energy Journal, vol. 31, no 2, pp. 27-52. DOI: 10.5547/ISSN0195-6574-EJ-Vol31-No2-2

Kuntze J.C., Moerenhout T. (2013) Local Content Requirements and the Renewable Energy Industry - A Good Match? Geneva, Switzerland: International Centre for Trade and Sustainable Development.

Kusek P., Silva A. (2018) What Investors Want: Perceptions and Experiences of Multinational Corporations in Developing Countries, The World Bank.

Lima-de-Oliveira R. (2020) Corruption and Local Content Development: Assessing the Impact of the Petrobras' Scandal on Recent Policy Changes in Brazil // The Extractive Industries and Society, vol. 7, no 2, pp. 274-282. DOI: 10.1016/j.exis.2019.08.004

Lin J. (2016) Alice H. Amsden's Contributions to Development Economics // Cambridge Journal of Regions, Economy and Society, vol. 10, no 1, pp. 77-81. DOI: $10.1093 /$ cjres/rsw040

Mabadi A.H. (2007) Transfer of Technology in Oil and Gas Con- 
tracts // SSRN Electronic Journal. DOI: $10.2139 /$ ssrn.1745426

Nwapi C. (2015) Defining the "Local" in Local Content Requirements in the Oil and Gas and Mining Sectors in Developing Countries // Law and Development Review, vol. 8, no 1, pp. 187-216. DOI: $10.1515 / \mathrm{ldr}-2015-0008$

Nwapi C. (2016) A Survey of the Literature on Local Content Policies in the Oil and Gas Industry in East Africa // The School of Public Policy, SPP Technical Paper, University of Calgary OECD.

O'Callaghan T. (2016) Reputation Risk and Globalisation: Exploring the Idea of a Self-Regulating Corporation, Edward Elgar Publishing.

Obeng-Odoom F. (2019) Oil, Local Content Laws and Paternalism: Is Economic Paternalism Better Old, New or Democratic? // Forum for Social Economics, vol. 48, no 3, pp. 281-306. DOI: $10.1080 / 07360932.2016 .1197844$

Rabiu A. (2013) Local Content Policy and the WTO Rules of Trade Related Investment Measures (TRIMS): The Pros and Cons // International Journal of Business and Management Studies, vol. 2, no 1, pp. 137-146 // http://universitypublications.net/ijbms/0201/pdf/RHS405.pdf, дата обращения 30.11.2020.
Ross M. (2013) The Oil Curse: How Petroleum Wealth Shapes the Development of Nations, Princeton University Press.

Schutte G. (2013) Brazil: New Developmentalism and the Management of Offshore Oil Wealth // Revista Europea De Estudios Latinoamericanos Y Del Caribe (European Review of Latin American and Caribbean Studies), no 95, pp. 49-70 // https://www.jstor. org/stable/23595692? seq=1\#metadata info_tab_contents, дата обращения 30.11.2020.

Tordo S., Anouti Y. (2013) Local Content in the Oil and Gas Sector: Case Studies, World Bank Publication.

Wade R. (2015) The Role of Industrial Policy in Developing Countries // Rethinking Development Strategies after the Financial Crisis - Volume I: Making the Case for Policy Space (eds. Calcagno A. et al.), pp. 67-78. UNCTAD.

Warner M. (2017) Local Content in Procurement: Creating Local Jobs and Competitive Domestic Industries in Supply Chains, London: Routledge.

Wilson J.D. (2015) Understanding Resource Nationalism: Economic Dynamics and Political Institutions // Contemporary Politics, vol. 21, no 4, pp. 399-416. DOI: $10.1080 / 13569775.2015 .1013293$ 